\title{
QUALITY OF CONTINUING ENGINEERS' PROFESSIONAL EDUCATION AT THE UNIVERSITIES OF RUSSIA
}

\author{
KVALITETA NASTAVE PROFESIONALNOG OBRAZOVANJA \\ INŽENJERA NA SVEUČILIŠTIMA U RUSIJI \\ Prof. dr. Irina O. Kotlyarova \\ Irina A. Voloshina, \\ South Ural State University, Chelyabinsk, Russia/Russia \\ E-mail: kio_ppo@mail.ru
}

UDK/UDC: 005.334:378.014.61

JEL klasifikacija/JEL classification: L15; I23

DOI: $10.30657 / \mathrm{hdmk} .2020 .15$

Prethodno priopćenje/Preliminary communication

Jezik/Language: Engleski/English

\begin{abstract}
The problems of engineers' education quality and their solving are considered in the context of historically existing and modern development trends of Russia. The article aims to reveal factors that affect the quality of continuing professional education of engineering personnel in Russia positively or negatively and to discuss measures for improving quality of training.
\end{abstract}

Key words: engineer' continuing professional education, quality, factors.

\section{INTRODUCTION}

The quality of engineering personnel training determines the level of economic development of the country, its competitiveness in the modern market of innovative information technologies. Historically, Russia has always been famous for the quality of training elite engineering personnel who made discoveries and world-class developments in aircraft, rocket engineering, and engineering technologies. However, both, a series of revolutions and wars, and political factors, created difficulties for the development of engineering education in the country. In the face of external threats and internal weaknesses, the problem of improving the quality of engineers' training intensified. 
Theory of education quality is well designed, ${ }^{1,2,3}$ as well as pedagogical technologies. ${ }^{4,5,6,7}$ But still technical academic staff, especially elderly part of it, is not inclined to use modern technologies and ways to improve educational quality. Though there are enough backgrounds for qualitative engineering education it does not fulfill its modern tasks. Based on the retrospective and SWOT analysis of the current education state the paper aims to search for the ways to improve the quality of engineering education in our country.

\section{A RETROSPECTIVE ANALYSIS OF THE DEVELOPMENT OF ENGINEERING EDUCATION IN RUSSIA}

To identify the consistent patterns and features of the Russian engineering education development, we turn to its retrospective analysis. ${ }^{8}$ The system of engineering education in Russia includes three historical subsystems, each of which goes through the stages of origin, formation, maturity and transformation, typical of systems.

The first subsystem originated in Peter's times (XVIII century). Educational reform was carried out in conjunction with reforms in other areas and aimed at creating a corps of domestic engineering personnel capable to raise the country's fast-growing economy. The period of the second half of the century (formation) was characterized by the appearance of a large number of professional educational institutions of different profiles and levels (quantitative accumulation), by the harmonious development of the system of education, production and science; engineering education was closely tied to specific industries, supported by the development of relevant sciences. Significant innovations of this period were: the permission of higher education for women and development of regulations on the university activities (1804). The rapid development of industry and the interests of industrialists contributed to the entry of engineering education into maturity stage in the late $19^{\text {th }}$ century - early $20^{\text {th }}$ century.

This system was destroyed together with tsarist Russia. It was replaced by the system of Soviet engineering education, the origin of which can be attributed to the $20^{\text {th }}-30^{\text {th }}$ of the $20^{\text {th }}$ century. The reasons for its inception were the needs of the newly formed state with reviving industry, science and culture, the creation of acceptable living conditions for the population suffering from devastation and hunger. The birth was hard. There was a lack of all resources. The ideals, many achievements and personnel of the past system were lost, and new ones had not been

\footnotetext{
${ }^{1}$ Irina O. Kotlyarova, "Systematization of quality criteria of university education, Bulletin of the South Ural State University", Series: Education, healthcare, physical education, No. 6, 2005.

2 Mark Maksimovič Potashnik, Management of the quality of education: A practice-oriented monograph and methodological manual, Pedagogical Society of Russia, 2000.

${ }^{3}$ Gennadiy N. Serikov, Sergei G. Serikov, "Education quality as a value, Bulletin of the South Ural State University. Series: Education, healthcare”, physical education, No, 29, No. 129, 2008.

${ }^{4}$ Enrique J. Agudo, Remedios Hernández-Linares, Mercedes Rico, and Héctor Sánchez, "Generic competences: Competence development in students of the Bachelor of engineering in industrial design and product development", Formacion Universitaria, 6, No. 5, 2013.

5 Juhani Anttila, V. Torvinen, and Kari Jussila, "Stimulating the quality of smart society through open scientific and artistic cooperation and lifelong learning", Continuing education. Vol. 1: Proceedings of the International Scientific and Practical Conference November 22, 2019.

${ }^{6}$ Marita Canina, Laura Anselmi, and Elizabetta Coccioni, Designing training plans in creativity techniques for companies. Paper presented at the Proceedings of the 15th International Conference on Engineering and Product Design Education: Design Education - Growing our Future, EPDE, 2013.

${ }^{7}$ Patricia J., Holahan, Zhen Z. Sullivan and Stephen K. Markham, Product development as core competence: How formal product development practices differ for radical, more innovative, and incremental product innovations. Journal of Product Innovation Management, 31, No. 2, 2014.

${ }^{8}$ D. L. Saprykin, Engineering Education in Russia: History, Concept, Prospects, Higher Education in Russia, No1, 2012.
} 
created yet. The new system was created in trial and error manner. At the same time, this period was characterized by an extremely high level and pace of development of pedagogical and psychological science to substantiate professional education.

The formation of the Soviet system of professional education accelerated in the late $30^{\text {th }}$ - early $40^{\text {th }}$ of the last century. These were hard years, when the country was recovering from the devastation caused by the revolution and the First World War, but there were already new aggressive threats. It was necessary to improve the quality of engineering education quickly, to increase the competitiveness of Russian industry, and raise the defense industry. The unexpected outbreak of World War II spurred this need. Despite war conditions, state policy focused on creating modern industry, improving its quality for reaching higher positions in the global economy. This entailed a new round in the development of engineering personnel. The development of professional education and training was stimulated by the needs of the military and defense complexes, and by acute shortage of qualified personnel, especially engineers. The best universities of the country, evacuated to its central regions, solved this urgent task in difficult educational conditions (war and post-war periods, lack of labor force). But it gave perfect results. The nomenclature of specialties of secondary and higher professional education has expanded significantly. Tasks of training personnel for professional education and advanced training of existing engineering personnel were set. A system of supplementary (additional, further) education for already working personnel, characteristic for the USSR continuing education, was born. ${ }^{9}$ In the peaceful $70-80^{\text {th }}$ of the $20^{\text {th }}$ century when other systems restored the system of professional education in the USSR again entered a period of maturity, arms race driven. The engineering education system of this period, at all levels, was considered to be one of the best in the world.

However, at the turn of the century, the professional education system entered again the state of reform (transformation of the system). The reasons for this were: external world trends and revolutionary transformations within the country, which could not but affect the education system. External factors included the phenomena of globalization, the internationalization of higher education and the tendency of harmonization of world systems of professional education. Internal factors included: the collapse of the USSR, reforms in all the areas, specific problems of higher education (elderly academic staff, not ready for internationalization and digitalization in higher education). Revolution is the typical condition for temporary decline. The problems of quality decline were caused by the spread of innovative phenomena of digitalization and internationalization, not sufficient readiness of academic staff of the mature generation for it. On the one hand, according to V. F. Pugach data, the number of 40-59 year old academic staff diminishes and the percentage of young and elderly university teachers is growing. ${ }^{10}$ One the other hand it means that in several years we are to expect the percentage growth of the middle age group of the academic staff. Together, internal and external factors have dealt a significant blow to the engineering education system, leading thereby to its complete transformation at the turn of the century. Thus, at the end of the twentieth century the stage of the emergence of the post-Soviet professional education system began. The transition to the new system was characterized by: a long period of reform from the end of the twentieth to the present; qualitative changes in the legislation; changes in education system itself, guidelines, methods, forms, means of education; orientation of engineering education towards harmonization with the world system and recognition of Russian universities in world rankings.

The main plans for the development of professional, in particular, engineering education, were: the introduction of a competency-based approach for designing expected results and

\footnotetext{
${ }^{9}$ T. G. Mukhina, E. V. Koposov and V. V. Borodachev History and perspectives of development of additional vocational education in Russia Volga scientific journal, Vol. 27, No. 3, 2013.

${ }^{10}$ V. F. Pugach, "The age of teachers in Russian universities: what is the problem? Higher education in Russia", No. 1, 2017.
} 
evaluating actual results; establishing a level system of professional education similar to world patterns; introduction of credit system; introduction of degrees and qualifications that are understandable in other countries of the world; humanization of universities; integration in universities of education and science. Today, during the formation of the post-Soviet system of engineering education, we see its characteristic manifestations: adoption of Federal Law 273 "On Education in the Russian Federation", which legislatively approved the changes; deep study of the theoretical prerequisites for the development of the professional education system (the level of development of pedagogical science at the end of the $20^{\text {th }}$ century and the beginning of the $21^{\text {st }}$ century); intensification of processes related to the internationalization and digitalization of higher education.

A retrospective analysis of the development of engineering education in Russia from the time of Peter the Great to the present has revealed the following important patterns:

- Russian subsystems of engineering education developed both in evolutionary (selforganization) and revolutionary manners;

- significant qualitative changes in the system of engineering education are determined by both internal and external factors;

- the most powerful driving forces for the development of engineering education in Russia are critical situations, including revolutions, wars, and others, causing an acute need for engineering personnel of the highest level, and leading to takeoffs in the development trajectories of professional education.

Features of the modern period turned our attention, firstly, to adjusting the quality of additional engineering education, which can solve the dual task: to strengthen the engineering resource of enterprises and provide a higher level of teaching by adult teachers at universities. Secondly we have chosen the method that allows studying influence of external and internal factors on additional engineering education - the SWOT analysis.

\section{METHODS TO STUDY QUALITY OF MODERN CONTINUING ENGINEERING EDUCATION}

In Russia, the continuing education of professionals for production purposes is usually called additional (further) professional education. In continuing professional education, engineers master new labor functions, new technologies for self determination in a changing professional world. Additional education has two types: retraining (issuing a diploma) and advanced training (issuing a certificate) (Federal Law "On Education in the Russian Federation" dated December 29, 2012 N 273-FL). Also there are many informal and informal types of continuing (including additional) education. The quality of education is not only the correspondence between the achieved results and the goals set, but also the value ${ }^{11}$ that determines the attitude in design and implementation of education process.

To determine the quality criteria for additional engineering education, to evaluate the project and expected results, we studied, firstly, the requirements for educational programs of a technical orientation and a modern engineer (Professional standards and Federal state educational standards of 28 and 40 groups describing the engineer activities). Secondly, the best practices of public accreditation in Russia and foreign countries (AEER (Russia), ABET (USA), ECUK (Great Britain), CCPE (Canada), IEAust (Australia), JABEE (Japan), etc.) were analyzed. Thirdly, the well-known criteria for the quality of education were analyzed. As we

\footnotetext{
${ }^{11}$ Gennadiy N. Serikov, Sergei G. Serikov, "Education quality as a value, Bulletin of the South Ural State University. Series: Education, healthcare", physical education, No, 29, No. 129, 2008.
} 
previously determined, basing on the literature analysis, the quality criteria for continuing education are divided into groups: the quality of the project of the engineering education process (goals, content, methods and forms, expected results, methods for measuring and evaluating them); the quality of educational and pedagogical interaction (procedural implementation); quality management of the process of continuing engineering education (project and real process); relevance of the real process to the project. ${ }^{12}$ The project quality criteria are determined on the basis of the requirements of the standards for a particular program of additional engineering education. The quality of the expected results in accordance with the modern paradigm is expressed in competencies (they are also contained in educational standards and requirements). The tasks for education are determined by most popular expectations (synthesis of hard and soft skill; manager skills; high tech skills; digital skills, etc.). ${ }^{13,14,15,16,17}$ In modern digital world the quality has special part of personal criteria connected with reserving the human essence of people. The model of the engineering education quality criteria is at fig.1.

Figure 1 . The model of continuing engineering education quality criteria

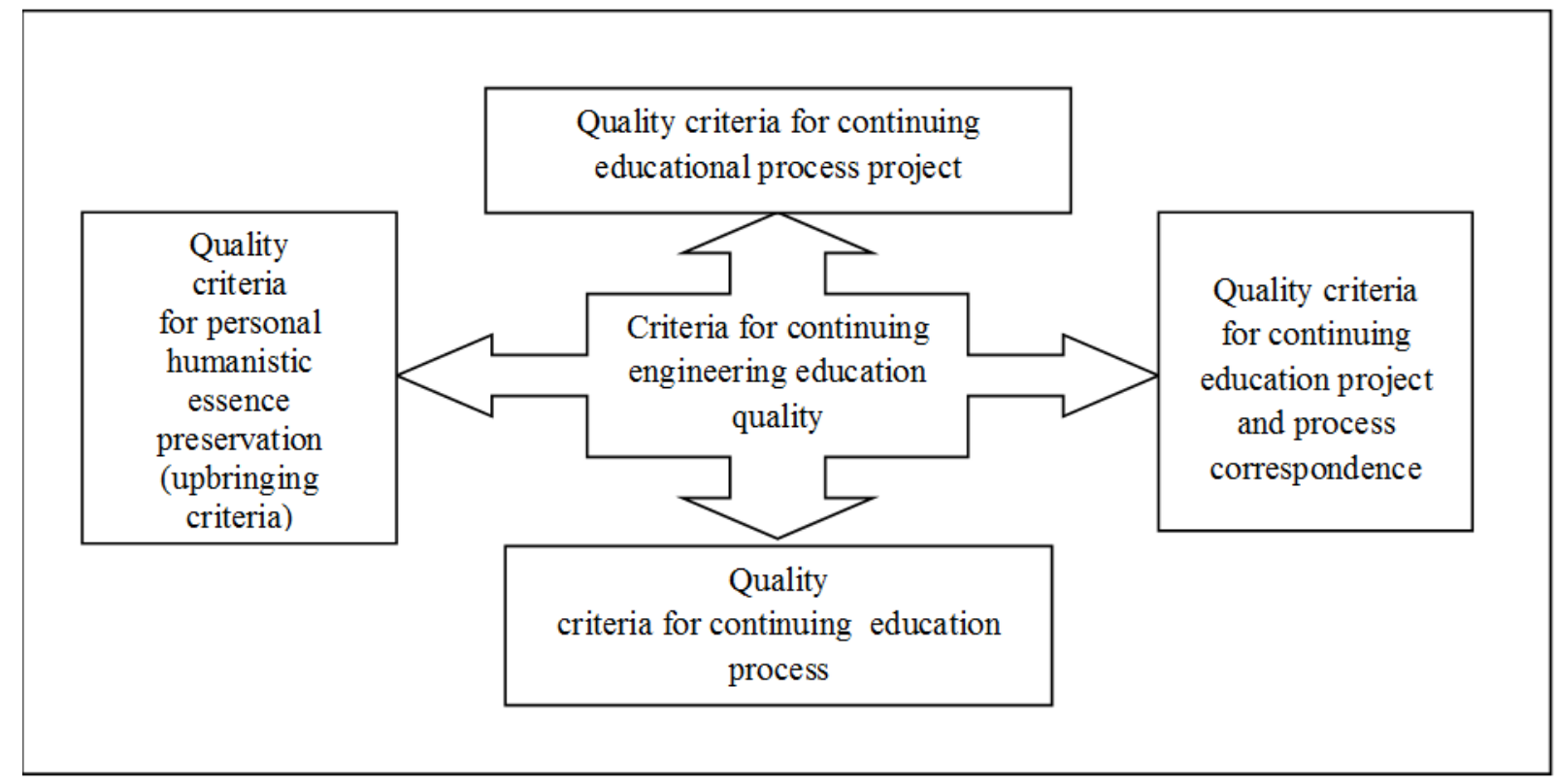

12 Irina O. Kotlyarova, "Systematization of quality criteria of university education", Bulletin of the South Ural State University, Series: Education, healthcare, physical education, No. 6, 2005.

${ }^{13}$ Enrique J. Agudo, Remedios Hernández-Linares, Mercedes Rico, and Héctor Sánchez, “Generic competences: Competence development in students of the Bachelor of engineering in industrial design and product development", Formacion Universitaria, 6, No. 5, 2013.

${ }^{14}$ Juhani Anttila, V. Torvinen, and Kari Jussila, "Stimulating the quality of smart society through open scientific and artistic cooperation and lifelong learning", Continuing education. Vol. 1: Proceedings of the International Scientific and Practical Conference November 22, 2019.

${ }_{15}$ Marita Canina, Laura Anselmi, and Elizabetta Coccioni, Designing training plans in creativity techniques for companies. Paper presented at the Proceedings of the 15th International Conference on Engineering and Product Design Education: Design Education - Growing our Future, EPDE, 2013.

${ }^{16}$ Patricia J., Holahan, Zhen Z. Sullivan and Stephen K. Markham, Product development as core competence: How formal product development practices differ for radical, more innovative, and incremental product innovations. Journal of Product Innovation Management, 31, No. 2, 2014.

${ }^{17}$ Irina A. Voloshina, Irina A. Kotlyarova, "Elite engineering education in mixed project groups, Proceedings of the $14^{\text {th }}$ International Conference Efficiency and Responsibility in Education, Prague, Czech Republic, EU, 8th $9^{\text {th }}$ June 2017. 
We studied the evolution of historical subsystems of engineering education due to internal reasons and due to self-organization. This prompted us to turn to the method of SWOT analysis in order to find ways to improve the quality of modern engineering education. The adequacy of the choice of this method is due to the fact that it consists in the analysis of the external and internal environment of the engineering education system and the analysis of possible mutual influences of the factors of these environments. This allows finding the best ways to develop organizations and systems based on the search for the necessary relationships between internal (strengths, weaknesses) and external (threats, opportunities) factors.

The method of SWOT analysis involves the analysis of the strengths and weaknesses of the organization or system, as well as threats and opportunities for them from the external environment. Therefore, additional research is required prior to the analysis. To apply the SWOT analysis method, it is necessary to obtain additional data, based on which the analysis is carried out. To obtain them, the following methods were used: analysis of scientific literature - to determine the prerequisites for studying the quality of additional engineering education; study of documentation and observation - to determine the internal factors for the development of continuing engineering education; analysis of scientific and reference sources to describe the state of the external environment. Using these methods, we obtained the following intermediate results.

\section{EXTERNAL ENVIRONMENT FOR THE CONTINUING ENGINEERING EDUCATION}

Environmental factors include threats from its individual systems and processes and opportunities that can be used to improve the quality of continuing engineering education.

The status of a factor (positive or negative; threat or opportunity), typically for the unity of opposites, can change to its antagonist. As it has been shown already, threats, which are negative environmental factors, at the same time, become a powerful driving force for the development of the system. Nevertheless, we define both groups of factors, introducing their conditional subdivision into two groups:

- The external threats $(\mathrm{T})$ of the national and world levels include two parts. Threats to the country's economy: destruction of many industries in the revolutionary period; the reduced funding for science-intensive and prestigious areas. Threats from the sides of foreign policy and foreign economic: sanctions policy when some previously available technical and information products become unavailable for purchase; high competition in high technology.

- Opportunities (O): Russian programs for the development of high technologies, digitalization of the economy (programs for the development of science and technology and higher education: "Scientific and technological development of the Russian Federation" (2019); "Scientific and technological development of the Russian Federation" (2019); "Digital economy RF") (2018)); "5-100 Project"; world known theories and experience in improving the engineers' education; MOOCs, making available information materials from the best manufacturers from different countries; sufficiently high level of development of educational methods that are adequate to engineering programs (simulation modeling, cases, contextual training, design method, etc.) in the global educational community.

Both threats and opportunities set directions and are the driving forces with different mechanisms for additional engineering education. 


\section{INTERNAL ENVIRONMENT FOR THE CONTINUING ENGINEERING EDUCATION}

First of all, it should be noted that the internal environment is described in terms of typical for the $21^{\text {th }}$ century trends: integration of education, science, entrepreneurship; internationalization; harmonization of the Russian and foreign structures of professional education; the unity and opposition of the competence and humanistic paradigm in professional education; informatization, digitalization of education and management. We will not argue that each of the trends can be attributed to a specific group of strength or weakness; they are too multidimensional and ambiguous. However, they should be taken into account when conducting a SWOT analysis:

- Strengths (S): continuing engineering education is carried out at universities with long-standing (centuries-old) traditions of training engineering personnel; universities have modern base and equipment; reach scientific schools continue to evolve; engineering education is consistent with targeted state programs; additional educational programs are carried out on the basis of professional standards, which reflect modern labor functions and actions of specialists; the achievements of pedagogical science and practice of continuing education are the base for engineering education development; the system of continuing education reached the maturity stage; great experience has been accumulated in Russian engineering education.

- Weaknesses (W): pre-existing system of engineering education was destructed; higher education is reforming and therefore it is not stable; programs are delivered by elderly staff who use traditional methods and means that have limited capabilities; teachers of the older generations belonging to the age group of 60-80 years, do not know digital technologies well and can neither prepare for their use nor use them in teaching; as quiz shows professors of technical disciplines pay attention mostly to the content of education, but ignore the benefits of modern educational technologies, which still have raising educational quality opportunities.

Thus, to force the growth problems the main step is to raise the qualifications of elderly engineers, to prepare the staff to deal with modern production and education technologies, to use all the existing opportunities.

\section{SWOT ANALYSIS FOR THE SAKE OF IMPROVING THE QUALITAY OF CONTINUING ENGINEERING}

We consider the preliminary work completed and determine the possibilities for improving the quality of engineering education. To do this, we turn to SWOT analysis, showing the mutual influence of factors of the external and internal environment, aimed at improving the quality of engineering education.

The $\mathrm{O}-\mathrm{S}$ relationship reveals the fact that the opportunities of the external national and world environment can be used them to improve the quality of continuing engineering education, basing on its strengths. The engineering education system is in high demand today, its high level restoration is relevant in the light of solving problems of development of the country's economy set by the government; programs for the development of science and technologies in the Russian Federation and universities may join them and have good support. Sanctions from the side of other countries also stimulate continuing engineering education as they force stating new tasks for development of high technology production. Thus threat turns into opportunity. 
The $\mathrm{S}-\mathrm{T}$ (1) relationship shows how to use strengths to overcome threats. Communication $S-T$ (2) makes it possible to use threats as driving forces for development (coinciding with $\mathrm{O}-\mathrm{S}$ relationship). Conditions of sanctions, when some previously available technical and information products became unavailable for purchase, require the development of substitute production and, therefore, engineers of a new level for projecting it. Diversification of the production sector and, as a result, diversification of the areas of training engineers are taking place as a consequence.

The $\mathrm{O}-\mathrm{W}$ connection takes advantage of opportunities to level weaknesses. The qualifications of aged engineering personnel should be upgraded for staffing the economy and for training the younger generation. More extensive use should be made of modern continuing education opportunities to improve the qualifications of elderly personnel and for basic education of youth.

The $\mathrm{T}-\mathrm{W}$ connection allows posing and giving answers to a number of questions. What threats should be neutralized taking into account weaknesses? Which weaknesses should be turned into strengths? What are the negative trends that need to be addressed? What are the weaknesses of engineering education in Russia most vulnerable to external threats? The answers to these questions allows us to think about overcoming weaknesses and turning them into strengths.

\section{CONCLUSION}

On the basis of SWOT analysis we output the following recommendations for improving the quality of continuing engineering education:

- Stating the skills of international scientific and educational activities and digital skills as the main goals for continuing engineering education.

- Stating all necessary engineers' skills as goal component of the educational process (project and real).

- Using the traditions of scientific schools, experience and high fundamental preparedness of old engineering personnel in combination with his further training for improving continuing engineering education.

- Using of sanctions as a leading and developing force for continuing engineering education.

- Raising the methodological level of the engineering academic staff for additional education.

- Using opportunities of modern educational technologies (interaction, flipped classroom, mixed education, case-study, and computer stimulation) for raising the level of the engineering educational project and educational process.

In general, by implementing these measures though given very schematically, we are improving the quality of continuing engineering education.

\section{Sažetak:}

\section{KVALITETA NASTAVA PROFESIONALNOG OBRAZOVANJA INŽENJERA NA SVEUČILIŠTIMA U RUSIJI}

Problemi kvalitete obrazovanja inženjera i njihovo rješavanje razmatraju se u kontekstu povijesno postojećih $i$ modernih razvojnih trendova Rusije. Cilj je članka otkriti čimbenike koji pozitivno ili negativno utječu na kvalitetu kontinuiranog stručnog usavršavanja inženjerskog osoblja u Rusiji, kao $i$ razmotriti mjere za poboljšanje kvalitete osposobljavanja.

Ključne riječi: kontinuirano stručno obrazovanje inženjera, kvaliteta, faktori. 


\section{LITERATURE}

1. Agudo, J. E., Hernández-Linares, R., Rico, Mercedes and H. Sánchez, "Generic competences: Competence development in students of the bachelor of engineering in industrial design and product development", Formacion Universitaria, Vol. 6, No. 5, 2013.

2. Anttila, J., Torvinen, V. and K. Jussila, "Stimulating the quality of smart society through open scientific and artistic cooperation and lifelong learning", Continuing education. Vol. 1, Proceedings of the International Scientific and Practical Conference November 22, 2019.

3. Canina, Marita, Anselmi, Laura and Elizabetta Coccioni, "Designing training plans in creativity techniques for companies", Proceedings of the $15^{\text {th }}$ International Conference on Engineering and Product Design Education, Design Education - Growing our Future, EPDE, 2013.

4. Holahan, J. Patricia, Sullivan, Z. Z. and S. K. Markham, "Product development as core competence: How formal product development practices differ for radical, more innovative, and incremental product innovations", Journal of Product Innovation Management, Vol. 31, No. 2, 2014.

5. Kotlyarova O. Irina, "Systematization of quality criteria of university education", Bulletin of the South Ural State University. Series: Education, healthcare, physical education, No. 6, 2005.

6. Mukhina T. G., Koposov E. V. and V.V. Borodachev, "History and perspectives of development of additional vocational education in Russia", Volga scientific journal, Vol. 27, No. 3, 2013.

7. Potashnik, M. M., Management of the quality of education: A practice-oriented monograph and methodological manual, Pedagogical Society of Russia, 2000.

8. Pugach, V. F. "The age of teachers in Russian universities: what is the problem?" Higher education in Russia, No. 1. 2017.

9. Saprykin, D. L. "Engineering Education in Russia: History, Concept, Prospects", Higher Education in Russia, No. 1, 2012.

10. Serikov, G. N. and S. G. Serikov, "Education quality as a value", Bulletin of the South Ural State University, Series: Education, healthcare, physical education, No, 29 (129), 2008.

11. Voloshina A. Irina and Irina O. Kotlyarova, "Elite engineering education in mixed project groups", Proceedings of the $14^{\text {th }}$ International Conference Efficiency and Responsibility in Education, Prague, Czech Republic, EU, 2017. 